\title{
The Considerations on a Classification Scheme for Community College Workforce Development Programs
}

\author{
Michael T. Miller (Corresponding author) \\ Department of Rehabilitation, Human Resources, and Communication Disorders, University \\ of Arkansas
}

Fayetteville, Arkansas 72701, United States

\begin{abstract}
Kenda S. Grover
Department of Rehabilitation, Human Resources, and Communication Disorders, University of Arkansas
\end{abstract}

Fayetteville, Arkansas 72701

Received: Aug. 20, $2021 \quad$ Accepted: Oct. 9, $2021 \quad$ Online published: Nov. 9, 2021

doi:10.5296/jpag.v11i4.18948～URL: https://doi.org/10.5296/jpag.v11i4.18948

\begin{abstract}
Community colleges actively engage in a broad array of pre- and in-employment workforce development programs. These programs have typically been categorized as credit or non-credit bearing, but this classification is problematic and does not account for the complexity of the type, size, or motivation for offering the program. This discussion categorizes workforce development programs based on their funding source, including federal, state, industry/private, institutional, and user based programs. This type of classification allows for a better understanding of who is being served by programs, how they might be used in the future, and ultimately, provides some foundation for program assessment.
\end{abstract}

Keywords: workforce development, job training, community college funding

\section{Introduction}

Workforce development programs are an important part of the mission of community colleges (Cohen \& Brawer, 2008). Through the delivery of programs that prepare pre- and in-service workers, community colleges provide important skills that are necessary to be a productive member of the labor force. With an emphasis on local industry, community colleges are uniquely situated to be a point of policy implementation as well as deliver 
academic programs to keep employees properly skilled and employed. Kasper (2003) noted "no other segment of postsecondary education has been more responsive to its community's workforce needs" (p. 14).

Workforce development is a complex scenario that does not fit easily into any particular structure (Eyster, Durham, Van Noy, \& Damron, 2016). Although most community colleges offer some version of workforce development, there is a lack of common nomenclature among institutions and how they develop, oversee, and fund their programs. For some colleges, all programs are externally funded, and in others, there is no external funding. The result is that workforce development has been broadly categorized as either credit-bearing programs or non-credit bearing programs. Looking further into these categories, however, reveals a more complex situation that requires a better understanding and description of how colleges are offering and evaluating workforce programs.

The purpose for the current examination was to offer a categorization scheme for workforce development programs based on their source of funding. This type of categorization would allow for administrators, as well as policy-makers and scholars, to be able to classify their programs for evaluative purposes, to better demonstrate their economic impact, to clarify their oversight and properly assign workloads, and to be able to judge the effectiveness of programs in meeting local labor needs.

A note in this discussion of workforce development programs is the vast collection and decentralization of programs across the United States. Some programs are organized around partnerships between community colleges and private sector business and micro-enterprise incubators, some are partnerships with public school districts, and others are even funded through international arrangements to provide skilled labor. This decentralization of workforce development makes it difficult, at best, for communities to plan long-term and strategically for sustained employment programs.

The classification for organizing workforce programs presented here is organized around the primary funding source of the program and includes federally sponsored programs, statesponsored programs, industry/privately sponsored programs, institutional academic programs, and user fee-based programs.

\section{Categories of Programs}

\subsection{Federally Sponsored Programs}

The federal government has a strong and sincere interest in helping business and industry be successful. When businesses succeed, their profits result in taxes being paid to various levels of government, workers are prosperous and do not rely on public subsidies, and employed workers more likely to avoid problematic situations (e.g., illegal activities, substance dependence, etc.). Employed workers are more likely to have health insurance, save for retirement, and provide to others in the form of volunteerism and philanthropy. An employed workforce, therefore, is a positive element in society (Office of Disease Prevention and Health Promotion, 2020). 
The federal government typically uses a philosophical approach that contracts with different types of agencies to train people to work in different types of disciplines, business areas, etc. In addition to being able to provide training, these programs can be used to leverage certain types of employment, such as in science, engineering, and math. One estimate has over 40 different workforce development programs spread across 14 federal agencies and an annual expenditure of over $\$ 17$ billion (Results for America, 2016).

Perhaps the broadest reaching workforce development legislation is the Workforce Innovation and Opportunity Act (WIOA). This legislation attempts to consolidate workforce training programs by federal and state agencies to create a more streamlined system that is usable by potential workers. The legislation provides money directly to states and other workforce training providers and was reauthorized in the spring of 2020. Across five different titles, the legislation addressed topics such as workforce training, adult literacy, and rehabilitation services. The legislation, however, cannot control for other initiatives, activities, resources, and programs offered by different state and federal agencies.

One of the major challenges for studying and describing federal workforce development programs is their lack of standardization and centralization within the federal government. This means there are many different agencies that provide workforce training opportunities. The Department of Labor, for example, funded $\$ 40$ million to be directed to community colleges to "address the skill development needs of employers and to support workers in gaining skills and transitioning quickly from unemployment to employment" (Department of Labor, 2021, I2).These awards, which ranged up to \$5 million, were awarded to either individual community colleges or consortium (collectives) of community colleges to provide training that was relevant and needed by these institution's local industry. Similarly, the Department of Defense awarded \$31 million in job training programs, including funding the 'Booming in STEM' program at Trident Technical College in Charleston, South Carolina. This training grant focused on training for STEM careers, including advanced manufacturing and cybersecurity (Department of Defense, 2021). Similarly, the Department of Defense, through the Navy, funded community colleges such as Alexandria Technical and Community College, Anne Arundel Community College, Blackhawk Technical College, the Community College of Baltimore, and Frederick Community College for specific training programs (Department of Defense, 2020).

Community colleges access federal funding through one of several different ways. The first, and most common, is through the application for funding as a "grant" or "sponsored program." For example, a community college could write a grant to the Department of Homeland Security to train airport security workers. Or a college could apply for a grant from the Department of State to provide language instruction in a specialized, highly needed language. In these situations, the federal department establishes a protocol of requesting the funds and receives applications during a specified period of time. These funding possibilities are typically advertised through the Federal Register (www.federalregister.gov), and by practice, each funding application is open for 30 days. Institutional representatives write and submit their grant proposals which are then graded or evaluated by an 'expert' panel which then makes recommendations for awards. The amount of awards typically varies and is 
dependent upon the amount that is authorized and allocated (noting the importance of this distinction).

The second way that community colleges access federal funding is through "state-pass through" awards. In these situations, state governments either make application for a federal grant or are authorized to receive a certain amount of funding for a specified activity through legislative authorization. The states receive money from the federal government and then award it to colleges or other providers based on some pre-specified criteria. Examples include funding from the US Department of Labor, providing \$150 million for workforce training in areas such as information technology, advanced manufacturing, cybersecurity, etc. (Department of Labor, 2020). The funding can come from the federal government to the state, and the state can then award the money to certain qualified institutions, including community colleges (for an example of this, see the Texas Workforce Commission, 2018).

\subsection{State Sponsored Programs}

States provide support for job training for the same reasons as the federal government; they want their citizens to be gainfully employed for all the reasons that come with making money and having responsibility (Francis \& Randall, 2017). State leaders, however, often also use workforce development programs to reflect a particular economic strategy (Education Commission of the States, 2020). The state might want, for example, to become a "destination" of a certain type of industry, such as health care or manufacturing. In such instances, the state invests in job training programs to build a future 'capacity' in those areas. For example, if a state wants to become a health care destination (meaning people come from all over a region or the country to use the health care expertise in that state), the state might provide money to train more health care professionals, such as Certified Nursing Assistants, Licensed Practical Nurses, medical doctors, specialized health care workers, etc.

The same can be noted for different types of manufacturing. One of the most economically desirable types of manufacturing is the automotive industry (Papatheodorou \& Harris, 2007). In addition to car assembly, there is the construction of the parts that can produce a large number of relatively high-paying jobs. A state might want to lure a car manufacturing plant by training a possible workforce, providing economic incentives to participate in job training (that is, the state might send funds to community colleges to pay for training for individuals who might work in car manufacturing, such as certain types of welders, quality control supervisors, and even certification for parts buying).

In these two examples, funding could come from different state agencies, and much like the federal government, there is no consolidated approach to workforce training. For health care workers, funding might come from different sources of state funds and be channeled through a State Department of Health Services. For the second example, training for the automotive industry might be coordinated through a State Department of Economic Development. These examples might also include funding being transferred to a single state agency to be distributed to educational providers, and the structure of such funding varies greatly among the different states. 
States also fund incentive-types of business and industry training, providing an 'incentive' for a business to remain within the state's geographic limits. The Department of Commerce in South Carolina, for example, provides incumbent worker training funds so that businesses can upskill or reskill their workers with funding support from the state (South Carolina Department of Commerce, 2021).

An interesting caveat in this discussion of de-centralized workforce development is that the federal Workforce Innovation and Opportunity Act (WIOA) does require a 'combined state plan' for a workforce development system, and many states make use of an administrative unit titled "Department of Workforce Development." These programs tend to be primarily occupational in orientation, and typically span non-degree to degree programs. These agencies host independent workforce development programs, but also collaborate with other state agencies in attempting to coordinate programs. These agencies typically have a central role in secondary and postsecondary workforce programs and can range from funding and encouraging industry-specific training to broader programs such as adult basic education and English as a Second Language. Again, these programs might be offered through secondary schools, using their physical facilities and instructional staff, as well as through technical institutes, community colleges, and four-year universities.

States also provide funding for workforce development through secondary and postsecondary education. Many states still fund vocational or occupational education, sometimes even referred to using the somewhat dated term "industrial education." These programs are primarily funded at the secondary level through formal programs offered in high schools (funded through local taxes as well as state assistance), and they also offer some of these programs through vocational and technical institutes as well as community colleges. Although these programs are tied to specific industries, they are not typically linked directly to a specific business. A school district or community college district could, for example, receive state funding to assist with training welders, although there is no guarantee of employment upon completion of the program.

A growing trend for these types of state programs is the partial-payer concept. This means that the state provides funding for a part of the program, but students are required to pay something to help defray program costs. This model can also be structured so that an institution can pay part of the cost rather than having the student pay. The welding program example might work like this: a state department recognizes that a region of the state has a need for an increase in certain types of welders. There might be five or six different businesses that need welders. The state, to satisfy those businesses' needs, provides funding to a local community college to expand its certificate program in welding. The state funding might pay $75 \%$ of the cost of the expansion, and the college would be required to pay the additional $25 \%$. The college would then require students to pay some discounted tuition to recoup their $25 \%$. The caution to the college, and ultimately a contributor to making decisions about which programs to offer, is the risk of not having adequate enrollment to cover their investment.

\subsection{Industry/Privately Sponsored Programs}


Most businesses and industries commit financial resources to the initial and continued training of their employees. These businesses can contract training for their employees through several different strategies. One is to complete the training "in-house," meaning, company employees design the curriculum and offer the training. These types of programs generally are highly industry and business-specific and take place in the business' physical facility. Employees are occasionally compensated for their training time (including bonus payments), and the training is seen as a required part of their jobs.

The second strategy is that the business makes use of commercial training products. These products might be offered through a specific business or even the manufacturer/producer of an aspect of the business. Training by Microsoft for the Microsoft suite might be available to a business through Microsoft, or, by a licensed Microsoft trainer. A company that repairs tractors might have annual training by the manufacturer of those tractors. An example of this is the John Deere Technician Training program at Fort Scott Community College in Kansas (Fort Scott Community College, 2021), and similar programs are offered by Southeast Community College in Nebraska and Walla Walla Community College in Washington. The same could hold true for machinery manufacturers, teaching employees modifications or differentiated uses for a piece of machinery from year-to-year. These types of training programs can be expensive and are highly specialized. Some training providers, for example, require employees to travel to certain geographic locations for training (such as a centralized manufacturing location). Some training also can be delivered directly to a company through electronic (online) modules, requiring the company to have a space dedicated for the training along with the necessary classroom/learning hardware.

A third strategy is for the business to contract with a third-party provider to complete the training. A major third-party provider is the community college (and to a lesser extent four-year universities), often organizing these types of training programs in a unit called "workforce education," or "contract training," or "continuing education." The community college has the flexibility of hiring individuals to conduct the training, and often has unique resources and expertise that can aid in the creation of training curriculum. Kilgore College in Texas, for example, has a broad Workforce Education office that includes contract training as well as business leadership. The Community College of Philadelphia similarly uses an office titled Workforce Development and Economic Innovation, and included within the office's responsibilities are contract training, workforce testing, grant funded job training opportunities, and among others, a center for small business.

When a community college is engaged in providing contract training, the college sets a fee for the training and typically hires non-full-time employees who are experts in the content area to complete the training. The training can occur on-site at the business, or, can take place on the college's campus. The college (or third-party provider) will typically build in a 'profit' margin to not only cover direct costs but also to help fund the office within the college. In some instances, the college will also contract with a company for the training, allowing the business to not have to worry about finding and writing contracts for the training, and, using college facilities for training. 
Many colleges will also incentivize training by linking these activities with credit-bearing certificates or degree programs, as illustrated by the John Deere program at Fort Scott Community College being linked to an associate's degree. The college can gain enrollment by providing some initial credit to a working employee who is being re-skilled and will frequently give this credit to the student for free. Additionally, the college can play an important role in providing a mechanism to transcript a learner's activities. This transcript activity may also be an important element in the issuing of micro-credentials, such as digital badges. Carroll Community College in Maryland, for example, provides digital badges that can be used across different media related portals such as "LinkedIn, Facebook \& Twitter, email signatures, digital resumes, online portfolios, personal and business websites. A digital badge lets you: instantly let employers know what you have to offer, share your resume-worthy achievements, explore labor market insights to search and apply for job opportunities" (Carroll Community College, 2021).

Colleges, especially community colleges, have become adept at developing rosters of trainers who can be used to work with business and industry. Training programs in areas such as Just-In-Time, Six Sigma, and ISO have been particularly popular and extend the very specific business training that is frequently offered.

State agencies recognize the role of community colleges in providing training and often provide different types and levels of funding for these contract training programs. Funding can come directly from a state department of workforce education or career education, but can also come from health and human services, education, and even corrections. Using community colleges is a strategy for the state to support business development and growth, while also focusing on the efficient nature of these institutions to deliver workforce education.

\subsection{Institutional Academic Programs}

Postsecondary institutions, including both community colleges and four-year universities approach workforce development in somewhat the same way. Both offer academic programs that are targeted at training students for specific workforce programs. Community colleges offer Registered Nursing (RN) degree programs, for example, that are linked to their Associate's degree programs. Four-year universities often then extend the RN to a Bachelor of Science in Nursing, for example, and in both instances, students are expected to enroll in and complete academic programs of study to have their degree awarded, and, these students are expected to pay for their enrollment.

Community colleges offer a broad array of workforce education programs, including health care, culinary arts, hospitality management, truck driving, gunsmithing, heating and air conditioning repair, welding, nursing, basic accounting, secretarial sciences, etc. These colleges work to align student completion of these programs with employment, although students enroll in these programs knowing that it is their responsibility to find employment upon successful completion of the academic program. Colleges provide a range of services to assist students in finding employment, including career services counselors, direct contact with hiring businesses, and even alumni networks and mentors. 
Community colleges use their protocols (often needs analysis) for determining which programs to offer, often relying on hiring market determinations to establish which programs to offer. With less of an emphasis on academic tradition, community colleges are nimble in offering programs (Cohen \& Brawer, 2008), being able to offer a program for several years and then to cancel the program and bring it back later when there is a demonstrated employment need (Kasper, 2003).

As noted earlier, many community colleges receive external support to offer certain workforce programs, whether from state agencies, employers, or even private foundations that want to see a particular labor pool enhanced. These funding agents might fund application fees, tuition, and even lab fees. One example is a local hospital paying for all student application fees to an RN program, hoping to increase the number of available nurses. Another example is a local restaurant chain paying student internship fees, such as transportation, to help grow the number of potential workers.

\title{
2.4 User Fee Based Programs
}

Colleges, including both two and four-year institutions offer workforce training programs that they believe, through their marketing research, will aid in the economic prosperity of both individuals and their service areas. These programs are generally offered for a certificate, but sometimes might lead to a diploma, include academic credit toward a degree, or even some formal certification. Other programs are stand-alone offerings focused on competency development and might include the basics of word processing or technology use. In each of these instances, however, the "end" user (the student) is required to pay a fee of some sort to subsidize the course. Many students enroll in these programs based on 'speculation,' meaning that they are enrolled and hope to improve their personal skill set so that they can find employment in some specific area.

Southeastern Community College in North Carolina, for example, included this partial listing of offerings:

\author{
General Workforce Training: Accounting Banking Bartending, Career \\ Readiness Certificate, Construction Trades (Masonry, HVAC, Electrical, \\ Carpentry) Culinary Arts, DSS Caseworker Phase I \& II Effective Teacher \\ Training Grant Writing, and Sign Language Small Engine Repair Spanish \\ Welding/Pipefitting (Southeastern Community College, 2021, II 25).
}

Programs that are based on user fees are designed to be taken by the general public and cost of the student's tuition is intended to pay for both the direct and indirect costs affiliated with the program. These programs are frequently organized under an office of 'continuing' or 'extended' education, and colleges offer these types of programs as long as they can generate adequate revenue and fulfill an employment need in a service area. 


\section{Discussion}

The offering of a classification system for workforce development programs does not inherently improve their offerings or access, but, it does provide the foundation for an initial conversation among policy makers and institutional leaders about where programs are housed and how they might better be cataloged and made visible. This visibility, importantly, extends beyond the campus, and must be more clearly shown to reach those desiring to enter the labor force or upgrade their existing skills. Additionally, having a good comprehension of what is offered and how these workforce programs are funded can be important as policy makers and institutional leaders work to be more strategic in aligning their offerings with immediate needs while building capacity for future employment demands.

Ultimately, this range of programs illustrates that individual agencies, and even colleges, structure their offerings to meet the needs that they interpret to the most important. Often, these needs are defined in a local, geographic area, typically the service area of a community college. But, if state-level leaders can bring college leaders together, states might find better efficiencies of scale and breadth of programs if they can assign roles to different colleges. A college that focuses on emerging technologies, one that focuses on health care related training, and another that focuses on vocational agricultural, for example, might allow colleges to create a better depth of programing and they can rely on other colleges to provide the breadth needed for a state. This synergistic approach relies on a systems-based thinking, where there is less emphasis on individual colleges, and more emphasis on achieving the outcome of a better skilled, trained, and educated workforce. This type of thinking, rarely popular for many reasons, including a mentality of wanting to be big and to do everything, means that community colleges collaborate not only with external stakeholders, but with each other.

This discussion also prompts a critical conversation about planning for the future and how community college leaders can best maximize their efforts in creating a diverse workforce training program. As noted, much training is immediate and corresponds to local demands, but technology changes rapidly and with this change, societal behaviors, including manufacturing and what is manufactured, currently and in the future will continue to change at a rapid pace. The traditional auto-industry could be replaced with electronic car manufacturing, resulting in a completely different set of assembly and maintenance skills. College leaders have to work together and with their private and public partners to figure out how to create those skills for the future.

Lastly, workforce leaders need to understand and appreciate the complexity of skill acquisition, and that many of the individuals who engage in training now will change jobs and occupations throughout their lifetime. The US Department of Labor projects that workers will change careers, not jobs, between 3 and 7 times in their working lives (McKay, 2020). This means that effective training has an element of understanding a working life, and the some of the skills learned for an immediate occupation might well transfer to another. This also has implications for understanding a competency based credentialling system that be transcripted, much like badges and micro-credentials, through the community college.

This offering of a classification system based on revenue source is but a beginning for a much 
larger, context-driven, conversation about where, how, and why workforce development exists and will exist in the future. There is a strong need for research that begins to outline how these systems of revenue, and priority, work together to compliment each other while building society's human capital.

\section{References}

Carroll Community College. (2021). Digital badges prove it. Show off your accomplishments with a digital badge. Retrieved online at www.carrollcc.edu/digitalbadges/

Cohen, A. M., \& Brawer, F. B. (2008). The American community college (5th ed.). Jossey-Bass.

Department of Defense. (2021). DoD awards \$31 million to National Defense Education Program science, technology, engineering, and mathematics. Washington: Author. Retrieved online at www.cto.mil/dod-awards-31-million-ndep-stem/

Department of Defense. (2020, July 23). Contracts for July 23, 2020. Washington: Author. Retrieved online at www.defense.gov/Newsroom/Contracts/Contract/Article/2286392/

Department of Labor. (2020, September 24). US Department of Labor announces availability of $\$ 150$ million to invest in workforce training for key US employment sectors. Washington: Author. Retrieved online at www.dol.gov/newsroom/releases/eta/eta20200924-0

Department of Labor. (2021, January 15). US Department of Labor awards \$40 million in strengthening community college training grants. Washington: Author. Retrieved online at www.dol.gov/newsroom/releases/eta/eta20210115-1

Education Commission of the States. (2020). 50-state comparison: Education and workforce development connections. Retrieved online at https://www.ecs.org/education-and-workforce-development-connections-state-profiles/

Eyster, L., Durham, C., Van Noy, M., \& Damron, N. (2016, March). Understanding local workforce systems. The Urban Institute. Retrieved online at https://www.urban.org/sites/default/files/publication/78496/2000648-understanding-local-wor kforce-systems_1.pdf

Fort Scott Community College. (2021). John Deere technician training. Retrieved online atwww.fortscott.edu/JohnDeere

Francis, N., \& Randall, M. (2017). State economic development strategies a discussion

framework. Urban Institute. Retrieved anline www.urban.org/sites/default/files/publication/89906/2001243-state-economic-development-st rategies-a-discussion-framework.pdf

Kasper, H. T. (2003). The changing role of community college. Occupational Outlook Quarterly, 46(4), 14-21.

McKay, D. R. (202, January 2). How often do people change careers? Careers. Retrieved 


\section{Macrothink}

Journal of Public Administration and Governance

from www.thebalancecareers.com/how-often-do-people-change-careers-3969407

Office of Disease Prevention and Health Promotion. (2020). Employment. Retrieved online at 222.healthypeople.gov/2020/topics-objectives/topic/social-determiants-healthy/interventionsresources/employment

Papatheodorou, Y., \& Harris, M. (2007, January 5). The automotive industry: Economic impact and location issues. Industry Week. Retrieved online at www.industryweek.com/the-economy/article/2198422/the-automotive-industry-economic-im pact-and-location-issues

Results for America. (2016). 7 ways to improve workforce outcomes using evidence: 2019 policy roadmap for state and local officials. Retrieved online athttps://results4america.org/page/workforce-policy-roadmap/

South Carolina Department of Commerce. (2021). Workforce training. Retrieved online at https://www.sccommerce.com/incentives/south-carolina-workforce-training

Southeastern Community College. (2021). Continuing education. Retrieved online athttps://www.sccnc.edu/continuing-education/

Texas Workforce Commission. (2018, August 16). About Texas workforce. Retrieved online at https://www.twc.texas.gov/about-texas-workforce

\section{Copyright Disclaimer}

Copyright for this article is retained by the author(s), with first publication rights granted to the journal.

This is an open-access article distributed under the terms and conditions of the Creative Commons Attribution license (http://creativecommons.org/licenses/by/4.0/). 